\title{
CORRIGENDUM
}

\section{$A S P P 1$, a common activator of TP53, is inactivated by aberrant methylation of its promoter in acute lymphoblastic leukemia}

X Agirre, J Román-Gómez, A Jiménez-Velasco, L Garate, C Montiel-Duarte, G Navarro, I Vázquez, M Zalacain, MJ Calasanz, A Heiniger, A Torres, JD Minna and F Prósper

Oncogene (2013) 32, 803; doi:10.1038/onc.2012.593

Correction to: Oncogene (2006) 25, 1862-1870; doi:10.1038/ sj.onc.1209236; published online 28 November 2005

The authors wish to correct the Oncogene paper cited above. In Figures $1 \mathrm{~b}$ and $\mathrm{d}$ two erroneous images were provided by
Dr Román-Gómez. The corrected Figures $1 \mathrm{~b}$ and $\mathrm{d}$ are reprinted here in its entirety. The authors apologize to the readers, reviewers, and editors for the mistake.

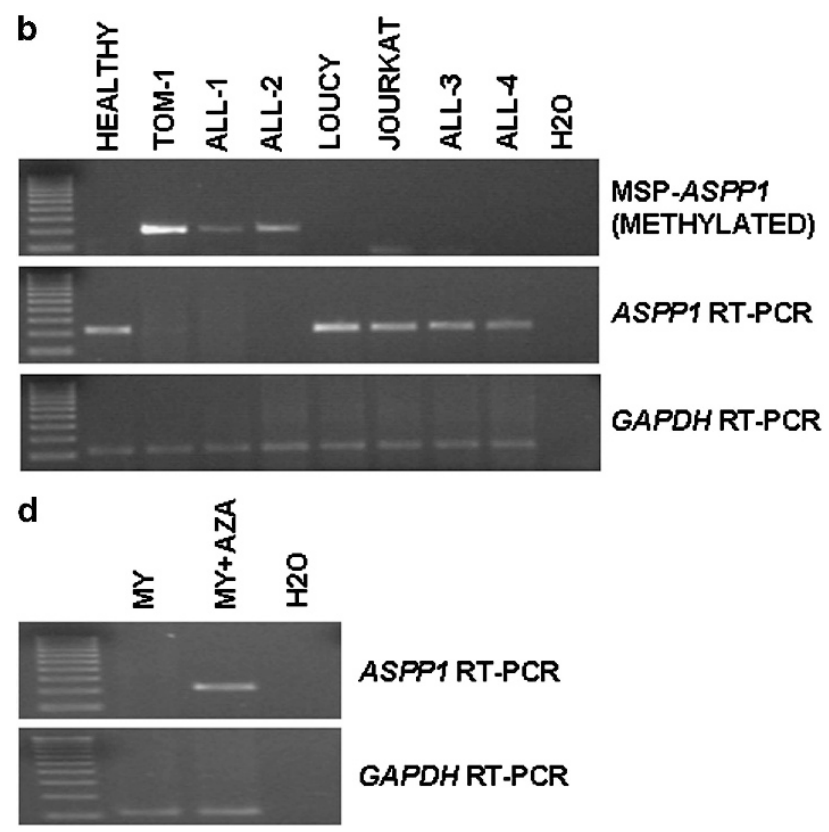

Figure 1. ASPP1 expression and promoter methylation in ALL-derived cell lines. (b) Analysis of the mRNA expression of ASPP1 in ALL-derived cell lines and patient samples (ALL-1, ALL-2, ALL-3 and ALL-4). ALL-derived cell lines: TOM-1, LOUCY and JOURKAT. HEALTHY: peripheral blood sample of healthy donor, used as a reference control. GAPDH mRNA amplification was used to assess RNA integrity and as reference gene. (d) Analysis of ASPP1 mRNA expression in MY ALL-derived cell line after treatment with $4 \mathrm{~mm}$ of 5-Aza-20-deoxycytidine. GAPDH mRNA amplification was used to assess RNA integrity and as a reference gene. 